\title{
DOMINASI PENGUASA KOLONIAL TERHADAP BUMIPUTRA DALAM SURAT KERAJAAN PONTIANAK ABAD KE-19: ANALISIS PASCAKOLONIAL
}

\author{
Bagus Kurniawan \\ Sastra Indonesia UNS \\ Jln. Ir Sutami No 36-A Kentingan Surakarta \\ Email: singawardhana@yahoo.com
}

\begin{abstract}
Abstrak
Penelitian ini mencoba menguraikan adanya dominasi penguasa kolonial terhadap rakyat terjajah yang terdapat dalam karya sastra Melayu klasik, terutama surat kerajaan. Surat kerajaan yang dijadikan sebagai objek kajian dalam tulisan ini adalah surat Kerajaan Pontianak yang dikirim oleh Pangeran Syarif Abu Bakar Al Qadri kepada J.F. Walrave van Nes, tanggal 16 Mei 1847. Di dalam surat tersebut terindikasi adanya ketimpangan hubungan antara subjek dengan objek. Penguasa kolonial memiliki kekuatan untuk mengatur dan mendominasi rakyat bumiputra. Relasi yang terjadi antara pihak Kerajaan Pontianak dengan penguasa kolonial bukanlah relasi yang memiliki posisi tawar politik yang sama, tetapi Kerajaan Pontianak bertindak sebagai pihak yang terdominasi secara politik maupun ekonomi. Oleh sebab itu, surat Kerajaan Pontianak tersebut akan dianalisis melalui teori poskolonial untuk melihat sebuah gambaran literer mengenai kondisi masa kolonialisme Kerajaan Pontianak pada abad ke-19.
\end{abstract}

Kata Kunci: kolonialisme, dominasi, surat kerajaan, poskolonial

\begin{abstract}
Process of colonialism in a long archipelago led to a number of colonial domination colonizers against the colonized. It can be seen in the classical Malay literature. Slightly, it is different from the concept of literature in the modern sense, in the sense of classical Malay literature, including royal scripts as a literary work. Therefore, the local royal scripts archipelago in the 18th century period 19th addressed to the colonial power are a classical Malay literature to inform the colonial domination of the colonized people. As such, this paper outlines the dominance of colonial powers against colonized peoples contained in the classical Malay literature, especially the royal letter. Royal scripts that serve as the object of study in this paper is a letter sent Pontianak Royal Prince Syarif Abu Bakar AlQadri to JF Walrave van Nes, dated May 16, 1847. The script indicates the inequality relationship between the subjects with the object. Colonial authorities have the power to regulate and dominate the native people. Relations between the Kingdom of Pontianak with no colonial power relations that have the same bargaining power politics, and the Kingdom of Pontianak act as a party dominated politically, and economically. Therefore, the Pontianak Kingdom of the letter will be analyzed through postcolonial theory to see a picture of the condition of literary colonialism Kingdom of Pontianak in the 19th century.
\end{abstract}

Keywords: colonialism, domination, royal scripts, postcolonial

\section{Pendahuluan}

Kawasan Asia Tenggara memainkan peran penting antara abad ke-15 sampai dengan abad ke-17 dalam bidang perdagangan rempahrempah. Perluasan perniagaan global abad ke-16 yang panjang, sangat memengaruhinya sebagai sumber rempah-rempah yang dibutuhkan oleh dunia internasional dan kawasan maritim yang melintang di sepanjang rute perdagangan. Asia Tenggara merupakan kawasan yang paling dipengaruhi oleh lonjakan aktivitas maritim
Cina pada permulaan abad ke-15. Kawasan ini merupakan sumber rempah-rempah, terutama lada yang menarik minat bangsa Spanyol berlayar ke Amerika dan ke Filipina, serta orang Portugal berlayar ke India sampai Asia (Reid, 2004: 3).

Mengembangkan alur pemikiran di atas, dapat disimpulkan salah satu daerah tujuan bangsa Barat adalah Asia Tenggara. Oleh karena itu pada umumnya, bangsa-bangsa di Asia Tenggara pernah mengalami penjajahan, kecuali Thailand (Lapian, 1975: 2). Sebagai salah satu 
negara yang terletak di Asia Tenggara, Indonesia, mengalami penjajahan mulai abad ke-18 sampai pertengahan abad ke-20. Dalam kurun waktu itu, bangsa Indonesia terpengaruh oleh bangsa kolonial pada berbagai dimensi. Kontak masyarakat bumiputra dengan kaum kolonialis Belanda tercermin di dalam dunia kesusastraan. Kasus-kasus semacam itu terdapat dalam dua periode kesusastraan, yakni dalam sastra lama dan sastra modern. Pada kesusastraan modern, kehidupan zaman kolonial dicerminkan oleh sastrawan-sastrawan yang berasal dari kaum terpelajar hasil Politik Etis Belanda. Sebagai contoh, sastrawan-sastrawan seperti, M. Yamin, Abdul Moeis, Marah Rusli, Soewarsih Djojopuspito, dan Sutan Takdir Alisjahbana merupakan para sastrawan yang mengenyam pendidikan Belanda. Pada sisi yang lain, pada khazanah sastra lama di Indonesia, gambaran kehidupan zaman kolonial ditulis oleh pujanggapujangga istana maupun penyalin naskah yang mengalami kontak dengan kehidupan zaman kolonial.

Salah satu produk sastra lama yang merefleksikan adanya situasi kolonial adalah surat-surat Melayu abad ke-18-19. Di dalam isi surat pada zaman itu menggambarkan kehidupan politik, budaya, ekonomi penguasa lokal terikat pada penguasa kolonial. Dengan kata lain, ada keterpaksaan, keterikatan, dan mungkin juga ketertundukan penguasa lokal terhadap penguasa kolonial yang direfleksikan oleh surat-surat kerajaan pada masa itu. Asumsi itu didasari bahwa adanya kontak antara penguasa kolonial dengan penguasa lokal seringkali melahirkan timbulnya pertentangan antara kekuatan dominan dengan pihak terjajah. Oleh karena itu, di dalam tulisan ini akan dibahas bagaimana ketimpangan hubungan antara penguasa kolonial dan penguasa lokal terefleksikan di dalam teks surat-surat kerajaan.

Objek kajian tulisan ini adalah surat yang dikirim Pangeran Syarif Abu Bakar Al Qadri kepada J.F. Walrave van Nes, tanggal 16 Mei 1847. Dominasi kolonial di dalam teks yang mencerminkan dimensi-dimensi apa saja dan sejauh mana dominasi kolonial itu bekerja melemahkan kekuatan negeri terjajah dianalisis dengan menggunakan teori kritik sastra pascakolonial. Oleh sebab itu, praktikpraktik kolonial yang mencerminkan dominasi terhadap negeri terjajah dapat diuraikan. Selain itu, analisis sastra pascakolonial diharapkan mampu menjembatani pemahaman teks dengan dimensi kesejarahannya sehingga pembaca dapat memaknai teks dari dimensi pascakolonial.

Dari sisi pernaskahan, objek kajian berupa naskah satu halaman berukuran 40,1 x $32 \mathrm{~cm}, 37$ baris. Kertasnya merupakan kertas Eropa yang agak tebal. Tinta yang digunakan berwarna hitam. Tulisan di dalam surat cukup jelas, namun karena teksnya terlalu panjang, kelihatan padat dan sesak. Keadaan naskah masih baik, hanya pada beberapa bagian sudah terdapat bercak-bercak coklat, misalnya pada bagian atas dan bawah surat. Tidak ada cap kertas. Stempel terletak di bagian atas sisi kanan, sejajar dengan awal teks. Bahannya dari lilin merah, tidak kelihatan tulisan di atasnya. Kepala surat terletak di tengah sisi atas, dengan tulisan biasa. Surat berisi penjelasan beserta keluhan yang penjang dan berbelit-belit tentang imbalan yang semestinya diterima negeri Pontianak dari pemerintah Belanda untuk hasil-hasil negeri. Imbalan itu tidak cukup untuk menutupi keperluan pemerintah Pontianak, tambahan lagi sebagian uang tidak mau diserahkan oleh Residen Belanda (Mu'jizah, 2009: 215).

Surat dari Kerajaan Pontianak itu tersimpan di perpustakaan Universitas Leiden dengan kode naskah Cod. Or. 2242-II (33). Oleh Mu'jizah (2009), naskah surat itu telah digunakan sebagai bahan disertasi yang berjudul Iluminasi dalam Surat-Surat Melayu Abad ke-18 dan ke-19. Oleh karena itu, suntingan teks dalam tulisan ini menggunakan suntingan Mu'jizah (2009). Dengan demikian, langkah-langkah penelitian filologis yang seharusnya dilakukan seperti studi katalog, inventarisasi naskah, transliterasi naskah tidak dilakukan di dalam penelitian ini.

\section{Hubungan Dikotomis Barat-Timur}

Hubungan antara Barat dan Timur merupakan hubungan yang bersifat dikotomis. 


\section{Jurnal Poetika Vol. 1 No. 1, Juli 2013}

Melalui dikotomi tersebut, Barat selalu diidentifikasikan sebagai ras yang unggul, kuat, cerdas, dan superior. Di lain pihak, Timur distereotipkan sebagai bangsa yang lemah, bodoh, daninferior. Tipe-tipe hubungan tersebut juga didukung oleh tesis Said (2001: 7) yang menyatakan hubungan antara Barat dan Timur adalah hubungan kekuatan dominasi, hubungan berbagai derajat hegemoni yang kompleks. Selanjutnya, terdapat sebuah konsep "Timur" ditimurkan tidak hanya karena ia didapati dalam keadaan "bersifat Timur", tetapi ia juga dapat dijadikan Timur. Berdasarkan pendapat tersebut, dapat diambil sebuah simpulan bahwa terdapat ukuran-ukuran yang konseptual-ideologis dalam mendefinisikan konsep geopolitik Barat dan Timur. Namun, perlu juga dikemukakan konsep yang mendikotomi konsep Barat dan timur itu melalui konfigurasi yang diciptakan oleh Barat. Artinya, seperangkat sistem yang digunakan untuk memetakan Barat dan Timur dikonstelasikan melalui prasangka, kepribadian, ukuran, paradigma, dan ego Barat. Oleh karena itu, dikotomi Barat dan Timur merupakan konsep geopolitik yang diciptakan oleh Barat untuk memisahkan ego Barat dengan Timur yang disebut dengan the other (sang lain).

Mobilisasi dikotomi yang dikembangkan bangsa Barat berkaitan erat dengan kesadaran baru Eropa. Gagasan identitas ego Eropa sebagai identitas yang lebih unggul dibandingkan dengan semua bangsa dan budaya non-Eropa merupakan paradigma kolektif (Said, 2001: 9). Adanya kesadaran ego Eropa mengenai keunggulannya dalam segala hal terhadap dunia Timur juga menimbulkan pengingkaranpengingkaran terhadap sejumlah sumbersumber peradaban Eropa yang berasal dari tradisi Islam.

Citra tentang keunggulan peradaban Eropa dan pelabelan bangsa Timur sebagai kaum inferior pada akhirnya telah menjadi bagian kolektif yang menyatu dalam struktur berpikir bangsa Barat. Akibatnya, timbul pandangan egois dari bangsa Barat yang memosisikan peradaban Barat sebagai peradaban teladan bagi seluruh dunia dan Eropa adalah pusat dunia. Imaji yang terbangun kemudian adalah peradaban Eropa merupakan suatu kreativitas brilian yang orisinal dan tidak terbangun di atas peradaban lama (Islam), serta tidak mengenal batas ruang dan waktu. Oleh karena itu, peradaban Eropa adalah peradaban ideal yang menjadi teladan bagi peradaban lain dan mewakili peradaban dunia (Hanafi, 2000: 131).

Paradigma kolektif bangsa Barat terhadap Timur senantiasa berkembang dari waktu ke waktu. Termasuk pula dalam hal ini ketika bangsa Barat (Eropa) tengah mengalami masa transisi ke arah era industri modern. Berbagai politik kepentingan dikampanyekan untuk mendukung upaya imperialisme Barat terhadap dunia Timur. Sebagaimana yang dikemukakan oleh Michael Doyle (dalam Said, 1995: 14) imperium adalah suatu hubungan, formal ataupun informal, dengan kondisi suatu negara menguasai kedaulatan politik efektif dari suatu masyarakat politik lainnya. Hal itu bisa dicapai dengan paksa melalui kolaborasi politik, melalui ketergantungan ekonomi, sosial, atau budaya. Tentu saja, pola-pola hubungan tersebut dikonstruksi oleh logika kolektif masyarakat Eropa terhadap dunia Timur.

Adanya kesadaran baru Eropa yang mengidentifikasi ego Eropa sebagai ras yang unggul dibandingkan Timur memosisikan Barat dapat berdiri dengan gagah sebagai pemimpin dunia. Kepemimpinan yang dikembangkan Barat dapat meliputi berbagai dimensi seperti politik, sosial, ekonomi, bahkan dalam peradaban. Oleh karena itu, terdapat hegemoni gagasan-gagasan Eropa mengenai dunia Timur yang mengulangi pernyataan mengenai keunggulan Eropa atas keterbelakangan Timur sehingga menutup peluang adanya pandangan-pandangan yang berbeda mengenai masalah ini dari pemikirpemikir yang lebih independen (Said, 2001: 9).

Jatuhnya pusat perdagangan Eropa di Konstantinopel pada tahun 1453 ke penguasa Islam turut serta mendorong pelaut-pelaut Eropa untuk mencari jalan baru ke dunia Timur India dan kepulauan rempah-rempah Nusantara (Djafaar, 2007: 17 dan Ratna, 2008: 3). Hal itu disebabkan sejak jatuhnya Konstantinopel 


\section{Jurnal Poetika Vol. 1 No. 1, Juli 2013}

ke penguasa Islam, pasokan rempah-rempah menjadi tersendat sehingga mengakibatkan harga rempah-rempah di pasaran Eropa melonjak. Untuk mengatasi hal itu, bangsa Barat berusaha mencari daerah penghasil rempahrempah.

Usaha bangsa Eropa (Barat) mencari daerah penghasil rempah-rempah dimulai pada abad ke-16 ketika dimulainya petualangan pelaut-pelaut Eropa ke dunia Timur. Kredo yang dipakai saat itu adalah misi kekayaan, kejayaan, dan pemberadaban bangsa Timur. Penaklukan Timur oleh Barat dalam pandangan ego Eropa bukanlah suatu upaya barbar, tetapi sebuah upaya untuk membawa negara terjajah dari masa prasejarah ke masa sejarah, dari kegelapan menuju cahaya, dan dari tiada menuju ada (Hanafi, 2000: 162). Sepihak dengan pendapat Hanafi di atas, Gramsci (Pozzolini, 2006: 154) memercayai bahwa setiap negara penjajah menyatakan kebijakan kolonialnya selalu membawa peradaban bagi negara terjajah. Hal itu bertolak belakang dengan kondisi yang sesungguhnya, proses yang tampak dari usaha-usaha bangsa Barat lebih mencerminkan penaklukan dan terjadi demi perhitungan ekonomi, bukan demi misi pemberadaban. Konsep tersebut merupakan pandangan yang penuh bias kultural, suatu usaha untuk bersembunyi dari dalih penjajahan

Kolonialisme diartikan sebagai penaklukan dan penguasaan atas tanah dan harta penduduk asli oleh penduduk pendatang. Dalam membentuk permukimam baru, terjadi hubungan yang kompleks dan traumatik dalam sejarah antara penduduk lama dengan pendatang baru. Kadang-kadang, pembentukan koloni baru ini ditandai dengan usaha membubarkan dan membentuk kembali komunitas-komunitas yang sudah ada dengan melibatkan politikpolitik perdagangan, penjarahan, pembunuhan massal, perbudakan, dan pemberontakan (Loomba, 2003: 2). Sistem penguasaan ini umumnya ditandai dengan kewajiban daerahdaerah koloni membayar pajak atau upeti kepada kerajaan pusat.

Gagasan di atas kembali dipertajam oleh Loomba (2003: 4) yang menyatakan kolonialisme modern tidak hanya mengambil upeti, harta benda, dan kekayaan dari negerinegeri jajahan. Akan tetapi, kolonialisme juga mengubah struktur perekonomian mereka, menarik negeri-negeri jajahan ke dalam hubungan yang kompleks dengan negaranegera induk sehingga terjadi arus manusia dan sumber daya alam antara negara-negara koloni dengan negara kolonialnya. Arus ini bekerja dua arah. Bahan-bahan produksi, yaitu berupa bahan mentah, tenaga kerja diangkut untuk mendukung proses produksi negara induk. Oleh karena itu, dapat disimpulkan ke arah mana pun manusia dan material itu mengalir, keuntungankeuntungannya selalu mengalir ke negara induk.

Kolonialisme dalam pandangan Loomba (2003: 2) menolak adanya sebuah proses identik dalam berbagai bagian dunia yang berbeda. Akan tetapi di lain pihak, di mana pun kolonialisme tumbuh selalu terjadi hubungan-hubungan yang paling kompleks dan traumatis dalam sejarah manusia antara para penduduk bumiputra dengan para pendatang baru. Proses membentuk sebuah komunitas dalam negeri baru tentu berarti membubarkan atau membentuk kembali komunitas-komunitas yang sudah ada di negerinegeri jajahan. Selain itu terjadi praktik-praktik termasuk perdagangan, penjarahan, negosiasi, perang, pembunuhan, perbudakan, dan juga pemberontakan. Melanjutkan pendapat di atas, dapat ditarik sebuah pengertian bahwa kolonialisme mengakibatkan timbulnya efekefek tertentu terhadap penduduk bumiputra. Kolonialisme tidak akan terlepas dari sebuah upaya perampasan harta benda maupun suatu bentuk dominasi-dominasi kebudayaan. Efekefek yang ditimbulkan akibat praktik-praktik kolonialisme itu dapat terlacak melalui dunia tekstual, termasuk dalam pengertian ini dunia karya sastra.

Studi-studi sastra akan memainkan peran kunci dalam proses penyampaian nilai-nilai Barat kepada pihak bumiputra, mengonstruksi budaya Eropa sebagai kebudayaan unggul, dan sebagai ukuran untuk nilai-nilai manusia sehingga berguna untuk mempertahankan 
pemerintahan kolonial (Loomba, 2003: 113). Selain itu, kesusastraan dan budaya sama sekali tidak antitesis terhadap lingkungan politis, tetapi sentral terhadapnya. Kesusastraan bandingan mengakui adanya interaksi yang mendalam dari berbagai literatur dan budaya itu terorganisasi secara hierarkis, dan asumsi sentralnya adalah Eropa berada di pusat dunia. Berkaitan dengan uraian di atas, kesusastraan pada masa kolonial merupakan elemen penting sehingga pantas untuk ditelaah dalam memahami wacanawacana kolonial.

\section{Kolonialisasi Belanda ke Kerajaan Pontianak}

Dalam masa separo pertama abad ke-19, Belanda mulai meluaskan kekuasaannya kepulaupulau luar selain Jawa, dan kekuatan-kekuatan Eropa yang lain mulai membuat tuntutan masingmasing terhadap Asia Tenggara (Cowan, 1970: 30). Kebanyakan usaha Belanda tidak bertujuan untuk kolonisasi, tetapi lebih dititikberatkan pada perjanjian-perjanjian yang menyebabkan penguasa lokal menyerahkan wilayah-wilayah kekuasaannya kepada pemerintah kolonial, serta menyerahkan perhubungan luar kepada Belanda. Dengan demikian, terciptalah kemungkinan untuk menarik kawasan-kawasan ini ke dalam kekuasaan Belanda sehingga Belanda dapat melarang adanya arus perdagangan dari kapal asing selain milik pemerintah kolonial HindiaBelanda. Di antara tahun 1843 sampai 1863 sebanyak lima puluh dua perjanjian telah dibuat dengan kerajaan-kerajaan Kalimantan, Sulawesi, dan pulau-pulau sebelah Timor.

Menurut Ricklefs (1991: 201), pada seperempat terakhir abad XIX perimbangan kekuatan militer berubah secara menentukan terhadap kerajaan-kerajaan Nusantara yang masih merdeka, dan inilah yang memungkinkan berlangsungnya tahap terakhir perluasan kekuasaan Belanda. Pada zaman kapal layar yang terbuat dari kayu dan senapan yang diisi peluru dari moncong larasnya, kesenjangan di bidang teknologi militer antara bangsa Eropa dan kerajaan-kerajaan di Nusantara tidak begitu besar. Akan tetapi, keadaan mulai berubah ketika kekuatan penjajah yang berkembang mulai menggunakan senapan yang diisi peluru di bagian belakang, mauser, kapal perang bertenaga uap, dan hasil-hasil militer lain dari suatu perekonomian industri. Pada saat itu, sebagian besar negara-negara praindustri Indonesia hanya dapat melawan dengan tekat dan senjata-senjata api yang kuno. Beberapa penguasa kerajaan-kerajaan yang masih merdeka berusaha memperbaiki perimbangan itu dengan jalan membeli persenjataan modern, tetapi mereka jarang sekali dapat menyamai kekuatan militer angkatan perang penjajah untuk waktu yang lama.

Kenyataan historis menunjukkan pada masa itu armada militer pemerintah kolonial Hindia-Belanda merupakan armada yang kuat sehingga mempunyai pengaruh yang cukup besar di Semenanjung Sumatra. Dengan kekuatan militer yang lebih kuat dibanding kerajaan-kerajaan di Nusantara tersebut, pemerintah kolonial Hindia-Belanda selalu menerapkan dominasi politiknya menjadi pola subjek-objek.

Di dalam teks adanya ketertundukkan penguasa lokal terhadap penguasa kolonial terlihat melalui sikap Pangeran Syarif Abu Bakar Al Qadri dari Kerajaan Pontianak. Penguasa Kerajaan Pontianak itu secara sadar menempatkan dirinya beserta kerajaannya sebagai daerah taklukan yang mengakui kekuasaan pemerintah koolonial Belanda di Batavia dan pemerintah pusat Kerajaan Belanda. Atas ketertundukan itu, secara sadar pula Pangeran Syarif Abu Dakar al Qadri beserta kerajaannya merasa membutuhkan perlindungan Kerajaan Belanda. Segala hal yang berkaitan dengan kehidupan pemerintah Kerajaan Pontianak diatur berdasarkan kebijaksanaan dan kearifan Belanda dan pemerintah kolonial. Situasi itu terlihat di dalam kutipan berikut.

"Bahwa ini waraqat al ikhlas wa tuhfat al jinas yang terbit daripada hati yang putih lagi suci serta jernih, maka disertakan dengan beberapa tabik dengan segala hormat selamat begitu banyak yaitu daripada Paduka Pangeran Syarif Abu Bakar Al Qadri Pontianak Ibn Almarhum 
Sri Paduka Sultan Syarif Qasim Al Qadri Pontianak senantiasa berlindungkan dirinya di bawah keadilan dan peliharaan Sri Paduka Maharaja Nederland dan Gupernemen Olanda serta Sri Paduka Yang Dipertuan Besar Gubernur Jenderal punya keadilan dan peliharaan pada kita sampai punya zuriat-zuriat yang muta'akbir di dalam negeri Pontianak, maka barang disampaikan Tuhan seru sekalian alam jua kiranya datang ke hadapan manjelis Sri Paduka yang maha bangsawan lagi setiawan yaitu sahabat kita Tuan Mister Johan Frederik Walrave van Nes Raad van India terhiasi dengan bintang mahaduri singa Nederland serta bersemayam di negeri Betawi" ( Surat kode Cod. Or. 2242-II (33), baris 1).

Ketertundukan politik yang terlihat dalam kutipan di atas ternyata juga mengimplikasikan situasi keterjajahan kepada Kerajaan Pontianak menjadi semakin kompleks. Jika sebelumnya ketertindasan politik hanya berada pada taraf kehilangan kemerdekaan politik, maka situasi semakin parah karena penguasa Kerajaan Pontianak juga merasa sebagai wilayah yang dipelihara dan dilindungi oleh pemerintah kolonial. Artinya, keterpeliharaan yang dieksplisitkan oleh penguasa Kerajaan Pontianak itu mencakup pula pada keterikatan dan ketergantungan politik-ekonomi kepada penguasa kolonial. Dengan kata lain, tidak ada posisi tawar yang kuat pada penguasa Kerajaan Pontianak dalam menghadapi kebijakankebijakan politik dan ekonomi penguasa kolonial meskipun sadar akan adanya suatu kerugian. Jadi, keberlangsungan kehidupan Kerajaan Pontianak sangat ditentukan oleh kebijakankebijakan pemerintah kolonial pada zaman itu.

Sesuai dengan yang telah dikemukakan sebelumnya bahwa ketertundukan penguasa lokal makin terasa kuat karena penguasa Kerajaan Pontianak terikat pada sistem-sistem ekonomi yang diterapkan oleh penguasa kolonial. Hal ini berarti terlihat adanya pengubahan sistem perekonomian pada Kerajaan Pontianak yang disesuaikan untuk memberikan keuntungan pada penguasa kolonial. Yang patut diingat dalam hal ini ialah sistem ekonomi yang diterapkan oleh penguasa kolonial terhadap kerajaan lokal merupakan sistem-sistem dagang yang menguntungkan pemerintah kolonial. Salah satu perjanjian dagang yang diungkapkan secara eksplisit di dalam teks adalah perjanjian yang dilakukan pada tangga 13 Juli 1823 (baris 4). Perjanjian tersebut mengakibatkan hasilhasil negeri Kerajaan Pontianak dijual kepada pemerintah kolonial. Akan tetapi, sesuai dengan politik ekonominya, Belanda membeli barangbarang itu dengan harga terlampau murah sehingga uang hasil penjualan hasil-hasil negeri Kerajaan Pontianak tidak dapat digunakan untuk mencukupi kebutuhan. Inilah suatu bukti sistem-sistem ekonomi yang diterapkan hanya menguntungkan pihak pemerintah kolonial sedangkan negeri terjajah (Kerajaan Pontianak) mengalami kerugian. Dengan demikian, kebijakan ekonomi yang diterapkan mengindikasikan adanya ketimpangan dominasi subjek-objek.

\section{Dominasi Ekonomi}

Telah disinggung sebelumnya bahwa sistem-sistem ekonomi yang diterapkan penguasa kolonial terhadap kerajaan jajahan tidak menggunakan prinsip kesejajaran. Strategi ekonomi yang diterapkan kepada Kerajaan Pontianak misalnya, selalu menciptakan kondisi-kondisi yang tidak menguntungkan bagi Kerajaan pontianak. Tercatat di dalam teks bahwa sejak tahun 1819 Kerajaan Pontianak telah melakukan perjanjian pedagangan dengan penguasa kolonial. Tepatnya tanggal 12 Januari 1819 telah ditandatangai sebuah perjanjian antara Komisaris Mayor Nahuijs dengan Pangeran Ratu Syarif Abu Bakar (baris 33). Sistem perdagangan yang diterapkan seperti itu merupakan sistem yang diwariskan oleh VOC. Pada abad ke-18, VOC memiliki hakhak khusus seperti membentuk tentara sendiri, mencetak uang, mengadakan perjanjian dagang, memaklumatkan perang dan damai sehingga VOC mirip dengan layaknya sebuah negara yang berdaulat di tanah jajahan (Boxer, 1983: 11). Setelah keruntuhan VOC pada abad ke-18, tanah jajahan diperintah langsung oleh pemerintah 
Kerajaan Belanda. Sejak saat itu, pemerintah kolonial Hindia-Belanda meneruskan usaha penguasaan rempah-rempah oleh VOC di Nusantara.

Dominasi ekonomi yang kuat memosisikan Kerajaan Pontianak tidak mendapatkan keuntungan dari perdagangan dengan pemerintah kolonial Belanda. Terlihat di dalam teks bahwa hasil-hasil negeri Pontianak tidak dihargai dengan semestinya. Ada hal yang lebih tidak adil dilakukan oleh pemerintah kolonial terhadap Kerajaan Pontianak. Adakalanya pengiriman hasil-hasil negeri Pontianak tidak sesuai dengan jumlah yang harus dibayarkan karena harus dikenakan pemotongan-pemotongan (baris 10). Tentu saja hal ini merupakan produk kebijakan yang diambil secara sepihak. Hal itu sekaligus juga merupakan sebuah bukti bahwa penguasa kolonial memerankan subjek sedangkan rakyat terjajah sebagai objek.

"Syahdan 5 dari bulan Januari tahun 1833 kita dapat perintah dengan misti daripada paduka Tuan s-y t-y-r residen besar setelah barat Pulau Borneo kasih perintah dengan misti potong dua ratus 200 rupiah kehidupan kita kurnia Gupernemen Nederland kepada kita setengah perak setengah tembaga di dalam satu-satu bulan kasihkan kepada sanak orang enam ini perkara terlalu sakit kita punya kehidupan. Maka kita tulis kepada Gupernemen Nederland serta Sri Paduka Yang Dipertuan Besar Gubernur Jenderal Jan Chretien Baud yang telah lalu di Betawi" ( Cod. Or. 2242-II (33)).

Penderitaan ekonomi rakyat terjajah semakin parah karena ada kecurangan-kecurangan yang dilakukan oleh pejabat-pejabat kolonial. Akan tetapi, dapat dikatakan juga bahwa sikapsikap pejabat kolonial yang curang itu sebagai keangkuhan karena pejabat kolonial itu tidak menyerahkan sebagian uang kepada Kerajaan Pontianak. Seperti halnya yang dilakukan oleh Residen Baron van Lijnden yang tidak mau menyerahkan uang sebesar Rp12,5 karena suatu alasan yang tidak jelas. Namun, pihak Kerajaan Pontianak juga tidak akan dapat berbuat apa- apa jika kebijakan yang dilakukan oleh Residen Baron van Lijnden itu merupakan perintah langsung dari pemerintah kolonial di Batavia.

"Paduka Tuan Residen Baron van Lijnden dia kata mau lihat lagi buku-buku. Kita bilang, janganlah Tuan tahankan uang kita dua belas setengah rupiah, jikalau dengan perintah Gubernemen Nederland apa boleh buat. Paduka Tuan Residen Baron van Lijnden dia kata, Bukan perintah Gupernemen. Kita bilang siapa punya perintah. Paduka Tuan Residen Baron van Lijndden dia kata, mau lihat buku-buku juga" (Cod. Or. 2242-II (33)).

\section{Inferioritas Kerajaan Pontianak}

Di dalam teks surat, terdapat dominasi yang mengakibatkan suatu permasalahan yang kompleks, yaitu munculnya inferioritas Kerajaan Pontianak terhadap penguasa kolonial. Secara politik, Kerajaan Pontianak mengakui kekuasaan penguasa kolonial atas negeri Pontianak. Secara nyata, situasi itu dieksplisitkan oeh Pangeran Syarif Abu Bakar Al Qadri Pontianak yang menyebutkan kerajaannya senantiasa berlindung di bawah keadilan dan peliharaan Sri Maharaja Nederland dan Gupernemen Olanda (baris 1). Melalui pernyataan tersebut dapat dikatakan bahwa secara sadar penguasa Kerajaan Pontianak mengakui bahwa mereka merupakan negeri jajahan. Konsekuensi dari situasi tersebut adalah mereka terikat pada atuiran-aturan kolonial yang sangat ketat. Di dalam bidang ekonomi, mereka diharuskan menjual hasil-hasil negeri Pontianak hanya kepada Belanda, sedangkan dalam bidang politik mereka dikebiri. Apa pun yang menjadi kebijakan pemerintah kolonial, bagi Kerajaan Pontianak harus dipatuhi, bahkan pengurangan bayaran sebesar Rp12,5 tanpa alasan yang jelas pun tidak menjadi masalah asalkan kebijakan itu diambil berdasarkan kebijakan pemerintah kolonial di Batavia.

"Paduka Tuan Residen Baron van Lijnden dia kata mau lihat lagi buku-buku. Kiota bilang, janganlah Tuan tahankan uang kita dua belas setengah rupiah, jikalau dengan perintah Gubernemen Nederland apa 
boleh buat. Paduka Tuan Residen Baron van Lijnden dia kata, Bukan perintah Gupernemen. Kita bilang siapa punya perintah. Paduka Tuan Residen Baron van Lijnden dia kata, mau lihat buku-buku juga.” (Cod. Or. 2242-II (33))

Situasi di atas menandakan bahwa pada aspek-aspek tertentu, Kerajaan Pontianak sudah mengalami sebuah fase inferioritas. Kerajaan Pontianak merasa pihak mereka sebagai pihak yang lebih rendah disandingkan dengan pihak kolonial walaupun di dalam teks, pihak Kerajaan Pontianak menganggap pemerintah kolonial sebagai sahabat mereka. Akan tetapi, realisasi hubungan persahabatan yang dieksplisitkan di dalam teks tidak mencerminkan hubungan persahabatan yang terjalin berdasarkan asas kesejajaran. Persahabatan pemerintah kolonial dengan Kerajaan Pontianak tidak lebih dari hubungan dominatif. Dominasi penguasa kolonial di dalam teks diaktualisasikan dengan menyebut pejabat kolonial yang bernama Johan Frederik Walrave van Nes Raad sebagai mahabangsawan. Dengan kata lain, pejabat kolonial yang disebut itu merupakan bangsawan tertinggi di negeri-negeri jajahan, melebihi bangsawan lokal.

Aparatur penguasa lokal seringkali digunakan Belanda sebagai agen kolonial untuk menggerakkan rakyat bekerja demi keuntungan kolonial (Darban, 1990: 5). Perubahan sistem ekonomi kerajaan yang menempatkan penguasa lokal tersebut menjadi pegawai kolonial turut mengondisikan inferioritas penguasa lokal. Sebagai contoh, di dalam teks dikatakan bahwa Kerajaan Pontianak setiap bulan mendapatkan uang dari pemerintah kolonial sebesar lima ratus rupiah. Hal ini mengindikasikan kehidupan kerajaan sangat tergantung oleh kebijakan pemerintah kolonial karena pihak kerajaan tidak diperkenankan untuk berdagang.

“....satu menantu laki-laki, serta kita punya cucu-cucu enam belas, sepuluh laki-laki, enam perempuan, serta kita punya kemenakan-kemenakan, serta dua anak pelihara laki-laki sudah beristri cucu Sultan Muhammad Zainal Abidin, serta kita punya orang-orang tiada berdagang sehidupnya kita dengan kurnia Gupernemen Nederland lima ratus rupiah setengah perak setengah tembaga sabansaban bulan sebab kita rasa..." (Cod. Or. 2242-II (33).

Pada akhirnya, sikap-sikap penguasa lokal terhadap pemerintah kolonial menjadi rendah diri. Apabila sebelumnya dijelaskan bahwa Kerajaan Pontianak merupakan daerah yang dilindungi dan dipelihara oleh penguasa kolonial, maka selanjutnya ide itu diaktualisasikan dengan pengubahan sistem ekonomi yang menggaji pejabat-pejabat tradisional menjadi pegawai kolonial. Oleh karena itu, hal ini mengindisikan rakyat terjajah makin lemah. Pada tingkat selanjutnya, di dalam teks inferioritas itu dieksplisitkan dengan posisi tawar politik yang rendah dan menyebut diri sebagai orang miskin di hadapan Belanda. Situasi ini berarti ada ketergantungan yang nyata antara pihak terjajah dengan penguasa kolonial.

"Sebab itulah kita pohonkan kepada Gupernemen Nederland serta Sri Paduka Yang Dipertuan Besar Gubernur Jenderal serta Sri Paduka sahabat kita punya peliharaan dan keadilan kepada kita sampai kepada kita punya zuriatzuriat yang muta'akhhir di dalam negeri Pontianak tetapi kita harap kepada Sri Paduka sahabat kita jangan buat kecil hati sebab permintaan kita yang miskin ini adanya. Lain tiada melainkan tabik dengan segala hormat yang diperbanyak-banyak kepada Sri Paduka sahabat kita jua adanya, tammat al kalam." (Cod. Or. 2242-II (33))

\section{Kesimpulan}

Setelah melakukan analisis terhadap naskah surat kode Cod. Or. 2242-II (33) diperoleh kesimpulan bahwa dominasi penguasa kolonial tidak hanya terdapat pada satu dimensi, tetapi terlihat pada beberapa dimensi yang lain. Melalui perjanjian dagang misalnya, penguasa kolonial mampu menekan penguasa tradisional melalui dua dimensi, yaitu dimensi ekonomi dan politik. Adanya keterkaitan perjanjian perdagangan mengakibatkan Kerajaan Pontianak mengalami 
dua hal yang sangat mengikat. Pertama, hasilhasil negeri Pontianak dimonopoli oleh penguasa kolonial. Hal ini berarti negeri Pontianak terikat perjanjian perdagangan dengan penguasa kolonial secara ketat. Kerajaan Pontianak tidak diperkenankan untuk melakukan hubungan dagang dengan pihak-pihak luar selain Belanda. Kedua, akibat dari konsekuensi tersebut harga jual hasil-hasil negeri Pontianak dihargai dengan sangat murah sehingga negeri Pontianak tidak dapat mencukupi kebutuhan dalam negeri malalui kerja sama perdagangan dengan penguasa kolonial. Dua hal tersebut pada akhirnya melemahkan kekuatan lokal karena pada praktiknya aparat-aparat tradisional juga berperan sebagai agen-agen kolonial.

Akibat yang paling kompleks dari dua hal di atas adalah terciptanya inferioritas penguasa lokal. Inferioritas ini dikondisikan oleh faktor-faktor yang telah disebutkan di atas ditambah dengan hilangnya kekuatankekuatan lokal yang berakibat ketergantungan kepada penguasa kolonial. Penguasa lokal telah kehilangan pengaruh politisnya karena sudah tercipta ketergantungan yang mutlak kepada penguasa kolonial, bahkan keberlangsungan Kerajaan Pontianak pun ditentukan oleh gaji yang diterima oleh pemerintah kolonial. Situasi demikian menimbulkan rasa rendah diri dengan menyatakan sebagai " kita yang miskin" kepada penguasa kolonial.

\section{Daftar Pustaka}

Boxer, C.R. 1983. Jan Kompeni dalam Perang dan Damai (1602-1799). Jakarta: Sinar Harapan.

Cowan, C.D. 1970. Tanah Melayu Kurun Kesembilan Belas: Asal-usul Politik British. Kuala Lumpur: Dewan Bahasa dan Pustaka Kementerian Pelajaran Malaysia.

Darban, Ahmad Adaby. 1990. Peran Serta Islam dalam Perjuangan Indonesia: Sebuab Kajian Sejarah Perjuangan Indonesia. Yogyakarta: Fakultas Hukum Universitas Islam Indonesia.

Djafaar, Irza Arnyta. 2007. Jejak Portugis di Maluku Utara. Yogyakarta: Ombak.
Hanafi, Hassan. 2000. Oksidentalisme: Sikap Kita Terhadap Tradisi Barat. Diterjemahkan oleh M. Najib Buchori. Jakarta: Paramadina.

Lapian, A.B. 1975. Manusia dan Kebudayaan di Asia

Tenggara: Kolonialisme di Asia Tenggara, seri studi wilayah nomor 2. Jakarta: Lembaga Research Kebudayaan Nasional-LIPI.

Mu'jizah. 2009. Iluminasi dalam Sura-Surat Melayu Abad ke-18 dan ke-19. Jakarta: KPG, Ecole Francais d Extreme- Orient, Pusat Bahasa-Departemen Pendidikan Nasional, KITLV.

Loomba, Ania. 2003. Kolonialisme/ Pascakolonialisme. Yogyakarta: Bentang.

Pozzolini, A. 2006. Pijar-Pijar Pemikiran Gramsci. Yogyakarta: Resist Book.

Reid, Anthony. 2004. Sejarah Modern Awal Asia Tenggara: Sebuah Pemetaan. Jak arta: LP3ES.

Ricklefs, M.C. 1991. Sejarah Indonesia Modern. Yogyakarta: Gadjah Mada University Press.

Said, Edward. 1995. Kebudayaan dan Kekuasaan: Memembongkar Mitos Hegemoni Barat. Bandung: Mizan.

-2001. Orientalisme. Cet. Ke-4. Diterjemahkan oleh Asep Hikmat. Bandung: Pustaka 